\title{
UJI EFEKTIVITAS EKSTRAK BIJI KETUMBAR (CORIANDRUM SATIVUM L.) TERHADAP GAMBARAN HISTOPATOLOGI GINJAL TIKUS HIPERKOLESTEROLEMIA DIABETES
}

\author{
Syarifah Nazira1, Maria Selvester Thadeus ${ }^{2}$, Niniek Hardini ${ }^{3}$ \\ ${ }^{1}$ Program Studi Kedokteran Program Sarjana, FK UPN Veteran Jakarta \\ Email: syarifahnazira49@gmail.com \\ ${ }^{2}$ Departemen Patologi Anatomi, FK UPN Veteran Jakarta \\ Email: maria_fkupn@yahoo.co.id \\ ${ }^{3}$ Departemen Patologi Anatomi, FK UPN Veteran Jakarta \\ Email:ninieksabar@gmail.com
}

Masuk : 23-06-2020, revisi: 27-08-2020, diterima untuk diterbitkan: 30-09-2020

\begin{abstract}
ABSTRAK
Diabetes Melitus (DM) merupakan suatu penyakit metabolik dengan karakteristik hiperglikemi yang terjadi karena kelainan sekresi insulin, kerja insulin atau kedua-duanya. Hiperglikemi persisten dapat memicu produksi stres oksidatif. Stres oksidatif dapat menyebabkan terjadinya hipertrofi glomerulus. Ekstrak biji ketumbar (Coriandrum sativum L.) berpotensi mengatasi stres oksidatif. Penelitian ini bertujuan untuk mengetahui efek pemberian esktrak biji ketumbar (Coriandrum sativum L.) terhadap gambaran histopatologi ginjal, kadar kolesterol darah, dan kadar gula darah tikus model hiperkolesterolemia diabetes. Sebanyak 30 ekor tikus putih jantan galur wistar, dikelompokkan menjadi lima kelompok dengan perlakuan berbeda yaitu: (K1) pakan standar dan aquades, (K2) pakan tinggi lemak, aloksan, dan glibenklamid 0,045mg/hari, (K3) pakan tinggi lemak, aloksan dan ekstrak biji ketumbar 300mg/kgBB/hari, K4) pakan tinggi lemak, aloksan dan ekstrak biji ketumbar 500mg/kgBB/hari, (K5) pakan tinggi lemak, aloksan, dan ekstrak biji ketumbar 700mg/kgBB/hari. Ekstrak biji ketumbar diberikan selama 28 hari. Hasil uji Wilcoxon menunjukkan ekstrak biji ketumbar dapat menurunkan kadar kolesterol darah, sedangkan hasil uji T berpasangan menunjukkan ekstrak biji ketumbar dapat menurunkan kadar guka darah sewaktu pada tikus model hiperkolesterolemia diabetes. Histopatologi ginjal dianalisis menggunakan uji Kruskal Wallis didapatkan $(\mathrm{p}=0,001)$ dan dilanjutkan dengan uji Mann-Whitney. Pada kelompok K4 terdapat penurunan luas glomerulus yang signifikan dibanding kelompok K3 dan K5. Kesimpulannya, esktrak biji ketumbar dapat menurunkan kadar kolesterol darah, kadar gula darah, dan pada dosis $500 \mathrm{mg} / \mathrm{kgBB} / \mathrm{hari}$ paling efektif untuk menurunkan hipertrofi gomerulus.
\end{abstract}

Kata Kunci: Coriandrum sativum L.; ekstrak biji ketumbar; hipertrofi glomerulus; kadar kolesterol darah; kadar gula darah

\begin{abstract}
Diabetes Mellitus (DM) is metabolic disease characterized hyperglicemia caused by abnormalities of insulin secretion, insulin sensitivity, or both of them. Persistent hyperglicemia can trigger the production of oxidative stress. Oxidative stress can cause glomerular hypertrophy. Coriander seed extract has the potential to overcome oxidative stress. This study aims to determine the effect of coriander seed extract to kidney histopathological examination, blood cholesterol, and blood sugar level in hypercholestrolemia diabetic rats. Samples consist of 30 males wistar rats were divided into five treatments i.e: (K1) standard feed and aquades, (K2) high-fat feed, alloxan, and glibenclamid 0,045 mg/day, (K3) high-fat feed, alloxan, and coriander seed extract $300 \mathrm{mg} / \mathrm{kgBW} / \mathrm{day}$, (K4) high-fat feed, alloxan, and coriander seed extract 500mg/kgBW/day, (K5) high-fat feed, alloxan, and coriander seed extract $700 \mathrm{mg} / \mathrm{kgBW} /$ day. Coriander seed extract was given for 28 days. The result of Wilcoxon test showed that coriander seed extract can reduce blood cholesterol level in diabetic hypercholesterolemia, meanwhile the result of paired T-test showed that it can reduce blood sugar level. Measurement of kidney's histopathological structure as glomerular area was analyzed by Kruskal Wallis test $(p=0,001)$ and continued with Mann-Whitney test. Group K4 can reduce glomerular area significantly compared with group K3 and K5. In conclussion, coriander seed extract can reduce blood cholesterol, blood sugar level and effectively reduce glomerular hypertrophy at dose of $500 \mathrm{mg} / \mathrm{kgBW} / \mathrm{day}$.
\end{abstract}

Keyword: Coriandrum sativum L.; coriander seed extract; glomerular hypertrophy; blood cholesterol level; blood glucose level 


\section{PENDAHULUAN}

\section{Latar Belakang}

Diabetes Melitus (DM) merupakan suatu kelompok penyakit metabolik dengan karakteristik hiperglikemi yang terjadi karena kelainan sekresi insulin, kerja insulin atau kedua-duanya (PERKENI,2015,hlm.1). The National Diabetes Data Group, menggunakan uji toleransi glukosa per oral 75 gram per $250 \mathrm{~mL}$ air sebagai kriteria diagnostik, memperikirakan prevalensi diabetes sebesar 6,6 persen dan 11,2 persen populasi menderita gangguan toleransi glukosa. Kebanyakan subjek yang didiagnosis gangguan toleransi glukosa atau diabetes dengan uji toleransi glukosa per oral tidak pernah menunjukkan adanya hiperglikemi puasa atau diabetes yang bergejala (Kasper et al., 2015, hlm. 2197).

Menurut World Health Organization (WHO), angka penyandang DM di Indonesia mengalami peningkatan dari 8,4 juta pada tahun 2000 menjadi sekitar 21,3 juta pada tahun 2030. Hal ini menunjukkan bahwa terdapat peningkatan angka penyandang DM 2-3 kali lipat pada tahun 2035. International Diabetes Federation (IDF) memprediksi adanya kenaikan jumlah penyandang DM di Indonesia dari 9,1 juta pada tahun 2014 menjadi 14,1 juta pada tahun 2035 (PERKENI, 2015, hlm. 1).

Peningkatan kejadian DM ini kemungkinan akan diikuti dengan meningkatnya kejadian komplikasi kronik DM, yaitu terjadinya penyumbatan pembuluh darah, baik mikrovaskular maupun makrovaskular yang terjadi karena adanya perubahan pada sistem vaskular. Perubahan ini salah satunya disebabkan karena stres radikal bebas. Radikal bebas dapat bereaksi dengan sel dan dapat menyebabkan kerusakan sel (Kisaoglu et al., 2013, p. 48). Radikal bebas juga berperan dalam progresivitas hiperglikemi akibat penurunan sekresi insulin dan aksi insulin (Sarian et al., 2017, hlm. 2 ). Salah satu yang disebabkan oleh radikal bebas ini adalah nefropati diabetik. Nefropati diabetik adalah abnormalitas struktural pada glomerulus dan eleman tubulus ginjal ditandai dengan adanya hipertrofi, meningkatnya ketebalan membran basal glomerulus dan pembentukan glomerulurosklerosis nodular, akumulasi komponen matriks ekstraselular, meningkatnya Glomerulus Filtration Rate (GFR) dengan hipertensi intraglomerular, proteinuria, hipertensi sistemik, dan kehilangan fungsi ginjal (Kajal and Singh, 2019, hlm. 2; A/L B Vasanth Rao et al., 2019, hlm. 755).

Nefropati diabetik adalah penyebab utama penyakit ginjal stadium akhir di seluruh dunia dan berhubungan dengan peningkatan risiko penyakit kardiovaskular (JorgeL. Gross et al., 2005, p. 164). Nefropati diabetik merupakan penyebab kematian tertinggi diantara semua komplikasi diabetes dan penyebab kematian tersering karena komplikasi kardiovaskular di Amerika. Kerusakan sel oleh radikal bebas ini dapat diatasi dengan pemberian antioksidan (Kisaoglu et al., 2013)

Antioksidan dapat ditemukan pada tanaman salah satunya pada biji ketumbar (Coriandrum sativum Lam' seeds ). Biji ketumbar memiliki kandungan flavonoid yang baik, dimana kandungan flavonoid tersebut adalah sebagai antioksidan dan antidiabetes (Pietta, 2000, p. 1035 ; Sarian et al., 2017, p. 2).

Penelitian yang dilakukan oleh Anu Kajal dan Randir Singh diketahui bahwa ekstrak biji ketumbar dengan dosis $100 \mathrm{mg} / \mathrm{kgBB} / \mathrm{hari}, 200 \mathrm{mg} / \mathrm{kgBB} / \mathrm{hari}$, dan 400mg/kgBB/hari, didapatkan bahwa dosis $400 \mathrm{mg} / \mathrm{kgBB} / \mathrm{hari}$ yang paling efektif untuk mengembalikan histologi jaringan ginjal tikus diabetik menjadi normal selama 45 hari (Kajal and Singh, 2019, p. hlm. 1). 
Berdasarkan hal tersebut, peneliti ingin mengetahui potensi ekstrak biji ketumbar dengan modifikasi dosis dari penelitian tersebut yaitu menjadi $300 \mathrm{mg} / \mathrm{kgBB} / \mathrm{hari}, 500 \mathrm{mg} / \mathrm{kgBB} / \mathrm{hari}$, dan $700 \mathrm{mg} / \mathrm{kgBB} /$ hari serta lama pemberian 28 hari terhadap gambaran histopatologi ginjal tikus jantan galur wistar model hiperkolesterolemia diabetes yang diberi pakan tinggi lemak dan diinduksi aloksan.

\section{Rumusan Masalah}

Berdasarkan latar belakang di atas, maka dapat dirumuskan masalah sebagai berikut : Bagaimana efek pemberian ekstrak biji ketumbar terhadap gambaran histopatologi ginjal tikus model hiperkolesterolemia diabetes?

\section{METODE PENELITIAN Desain Penelitian}

Jenis penelitian yang dilakukan dalam penelitian ini yaitu penelitian eksperimental dimana penelitian dilakukan dengan melakukan percobaan yang bertujuan untuk mengetahui pengaruh dari perlakuan atau percobaan tersebut. Rancangan yang digunakan adalah rancangan Posttest dengan kelompok kontrol (Posttest Only Control Group Design) untuk variabel gambaran histopatologi ginjal, selain itu pada penelitian ini dilakukan pretest dan posttest terhadap pengukuran kadar kolesterol dan kadar gula darah sewaktu tikus putih, setelah itu hasil yang didapat dari masing-masing kelompok dibandingkan (Dahlan, 2014, hlm. 110).

\section{Waktu dan Tempat Penelitian}

Penelitian ini dilakukan pada bulan November 2019 di Laboratorium Farmakologi dan Terapi Fakultas Kedokteran Universitas Padjajaran. Pembuatan preparat akan dilakukan di Laboratorium Patologi Anatomi Fakultas Kedokteran Universitas Padjajaran dan pembacaan hasil dilakukan di Laboratorium Patologi Anatomi Fakultas Kedokteran UPN "Veteran" Jakarta.

\section{Subjek Penelitian}

Sampel penelitian berupa tikus putih (Rattus norvegicus) sebanyak 30 ekor yang memenuhi kriteria inklusi yaitu berjenis kelamin jantan, berumur 2-3 bulan dengan berat badan 180 200 gram, dan tidak cacat secara anatomi, serta glukosa darah dan kolesterol awal dalam batas normal. Tikus diperoleh dari Laboratorium Farmakologi dan Terapi Fakultas Kedokteran Universitas Padjajaran Bandung.

\section{Perhitungan Besar Sampel}

Perhitungan jumlah sampel pada penelitian ini ditentukan dengan menggunakan rumus Federer. Berdasarkan hasil perhitungan didapatkan jumlah sampel sebanyak 5 ekor tikus pada setiap kelompok. Jumlah sampel yang dibutuhkan minimal sebanyak 25 ekor tikus, tetapi untuk menghindari drop out, maka ditambahkan 1 ekor tikus pada setiap kelompok, sehingga jumlah sampel pada penelitian ini adalah 30 ekor tikus.

\footnotetext{
Alat dan Bahan

Alat yang digunakan adalah object glass dan cover glass, mikroskop, kertas saring, sonde oral, corong gelas, spuit injeksi, sarung tangan, spektrofotometri, minor set, kapas, timbangan, masker dan penutup, kandang, dan tempat makan minum tikus, sedangkan bahan yang digunakan adalah aloksan, ekstrak biji ketumbar, glibenklamid, pewarnaan Hematoksilin-Eosin, ketamin, alkohol $70 \%, 80 \%, 90 \%, \mathrm{NaCl} 0,9 \%$, larutan $\mathrm{BNF} 10 \%$, parafin, xylol, pakan tinggi lemak, pakan standar, dan aquades.
} 


\section{Prosedur Penelitian}

Penelitian dilakukan setelah izin etik disetujui oleh Komisi Etik Penelitian Kesehatan Universitas Pembangunan Nasional "Veteran" Jakarta pada tanggal 30 Desember 2019 dengan nomor ethical approval B/2272/XII/2019/KEPK.

Penelitian diawali dengan pembuatan ekstrak biji ketumbar dilakukan di Balai Penelitian Tanaman Rempah dan Obat (BALITTRO), Bogor, Jawa Barat. Biji ketumbar sebanyak $1 \mathrm{~kg}$ ditimbang kemudian dihaluskan dengan menggunakan blender, setelah itu dimaserasi dengan etanol 95\% sebanyak 1 liter selama 48 jam. Kemudian hasil maserasi disaring dan diambil larutan hasil maserasi, lalu dimasukkan ke evaporator dengan suhu $50^{\circ} \mathrm{C}$ untuk memisahkan etanol dan ekstraknya. Setelah itu hasil ekstrak dimasukkan ke dalam oven dengan suhu $40^{\circ} \mathrm{C}$ hingga ekstrak berbentuk kental (Yulianty et al., 2015, hlm. 13).

Pada penelitian ini terdapat 5 kelompok tikus yang diberikan perlakuan yang berbeda-beda yaitu kelompok I(K1) sebagai kontrol negatif hanya diberikan aquades dan pakan standar Bravo-512, kelompok II(K2) sebagai kontrol positif diberikan aquades, pakan tinggi lemak, diinduksi aloksan dan glibenklamid, kelompok III(K3) sebagai kelompok perlakuan 1 diberikan aquades, pakan tinggi lemak, diinduksi aloksan, dan diberikan ekstrak biji ketumbar dosis 300mg/kgBB/hari, kelompok IV(K4) sebagai kelompok perlakuan 2 diberikan aquades, pakan tinggi lemak, diiunduksi aloksan, dan diberikan ekstrak biji ketumbar dosis $500 \mathrm{mg} / \mathrm{kgBB} / \mathrm{hari}$ dan kelompok V sebagai kelompok perlakuan 3 diberikan aquades,pakan tinggi lemak, diinduksi aloksan, dan diberikan ekstrak biji ketumbar dosis $700 \mathrm{mg} / \mathrm{kgBB} / \mathrm{hari}$. Setelah diaklimatisasi seminggu, tikus kelompok I diberikan pakan standar dan tikus kelompok II, III, IV, dan V diberikan pakan tinggi lemak selama 5 minggu. Keesokan harinya, dicek kadar kolesterol total darah dan kadar gula darah sewaktu tikus, lalu tikus kelompok II, III, IV, dan V diberikan aloksan. Tikus kelompok I diberikan pakan biasa, tikus kelompok II, III, IV, V diberikan pakan tinggi lemak pada hari itu. Keesokan harinya dicek kadar glukosa darah sewaktunya. Jika kadar glukosa darah sewaktu tikus kelompok II, III, IV, IV $\geq 135 \mathrm{mg} / \mathrm{dL}$ maka tikus telah mengalami diabetes. Keempat kelompok tikus tersebut dengan kadar glukosa darah $<135 \mathrm{mg} / \mathrm{dL}$ dieksklusikan dari penelitian. Selain itu, tikus kelompok II diberikan glibenklamid selama 4 minggu. Tikus kelompok III, IV, dan V diberikan ekstrak biji ketumbar selama 4 minggu. Setelah 4 minggu, dilakukan pengecekan gula darah dan kolesteol total tikus lalu tikus dianestesi dengan ketamin $0,3 \mathrm{~mL}$ secara intramuskular dan diterminasi menggunakan minor set.

Kemudian sampel ginjal diambil untuk dibuat preparatnya dengan pewarnaan Hematoksilin dan Eosin (HE) dan dilakukan pembacaan di bawah mikroskop elektron dengan pembesaran 400x lalu dinilai kerusakannya dengan menilai luas 25 glomerulus yang diambil secara acak di setiap sajian preparat ginjal.

\section{Analisis Data}

Data yang diperoleh dianalisis menggunakan software statistik. Kadar kolesterol darah tikus dianalisis menggunakan metode uji Wilcoxon, kadar gula darah sewaktu dianalisis menggunakan 
motode uji $\mathrm{T}$ berpasangan dan hasil luas glomerulus dianalisis menggunakan metode uji Kruskal Wallis yang kemudian dilanjutkan dengan uji Mann-Whitney.

\section{HASIL DAN PEMBAHASAN}

Pada penelitian ini didapatkan data kadar kolesterol total darah setelah pakan tinggi lemak dan sebelum perlakuan, kadar gula darah sewaktu sebelum penginduksian aloksan, setelah penginduksian aloksan, dan sebelum perlakuan, dan gambaran hitopatologi ginjal didapatkan pada akhir penelitian setelah pembedahan tikus.

Tabel 1. Hasil Rerata Kadar Kolesterol Total Darah Sumber Tabel: Data Primer, 2020

\begin{tabular}{cccc}
\hline Kelompok Tikus & $\begin{array}{c}\text { Setelah Pakan } \\
\text { Tinggi Lemak } \\
(\mathbf{m g} / \mathbf{d l}) \pm \mathbf{~ S D}\end{array}$ & $\begin{array}{c}\text { Setelah Perlakuan } \\
(\mathbf{m g} / \mathbf{d l}) \pm \text { SD }\end{array}$ & Selisih \\
\hline K1 & $49.333 \pm 4.7188$ & $48.833 \pm 2.5216$ & 0.50 \\
\hline K2 & $92.133 \pm 8.7865$ & $88.333 \pm 37.0108$ & 3.80 \\
\hline K3 & $109.483 \pm 15.6813$ & $69.533 \pm 11.3156$ & 39.95 \\
\hline K4 & $93.417 \pm 6.5126$ & $57.917 \pm 9.0912$ & 35.50 \\
\hline K5 & $96.033 \pm 14.5407$ & $74.167 \pm 22.2447$ & 21.86 \\
\hline
\end{tabular}

Penghitungan kadar kolesterol darah setelah diberikan pakan tinggi lemak menunjukkan bahwa rerata kadar kolesterol darah tikus kelompok 2, 3, 4, dan 5 lebih tinggi daripada kelompok kontrol negatif. Hal ini menunjukkan bahwa pemberian pakan tinggi lemak pada tikus kelompok 2, 3, 4, dan 5 menyebabkan hiperkolesterolemia. Hiperkolesterolemia dapat menyebabkan resistensi insulin (Hao, et al., p. 2328).

Hasil kadar kolesterol darah setelah perlakuan didapatkan bahwa terdapat penurunan rerata kadar kolesterol darah kelompok 2, 3, 4, dan 5. Penurunan yang dialami oleh kelompok 2 yaitu kelompok yang diberikan glibenklamid $0,045 \mathrm{mg}$ /hari, secara kuantitatif tidak signifikan sesuai dengan penelitian yang dilakukan oleh Mughal dkk. (2019), karena glibenklamid tidak mempengaruhi metabolisme kolesterol. Secara kuantitatif, penurunan yang dialami kelompok 3, 4, dan 5 yang diberikan ekstrak biji ketumbar dengan masing-masing dosis, cukup signifikan sesuai dengan penelitian yang dilakukan oleh Kajal dan Singh (2019).

Hasil uji Wilcoxon didapatkan bahwa kelompok yang memiliki nilai $\mathrm{p}<0,05$ atau memiliki perbedaan bermakna adalah kelompok perlakuan 1 kelompok yang diberikan ekstrak biji ketumbar 300mg/kgBB/hari dan perlakuan 2 kelompok yang diberikan ekstrak biji ketumbar $500 \mathrm{mg} / \mathrm{kgBB} / \mathrm{hari}$ dengan masing-masing penurunan sebesar 39,95mg/dL dan 35,23mg/dL, namun penurunanya tidak mencapai kadar kolesterol normal tikus yaitu sebesar $10-54 \mathrm{mg} / \mathrm{dL}$. Penurunan kadar kolesterol darah pada kelompok ini diakibatkan oleh kandungan flavonoid biji ketumbar. Flavonoid dapat meningkatkan aktivitas reseptor LDL, sehingga perpindahan LDL dari plasma meningkat (Joshi et al., 2012). 
Pada penelitian ini, kelompok perlakuan 3 yang diberikan dosis ekstrak biji ketumbar $700 \mathrm{mg} / \mathrm{kgBB} /$ hari memiliki nilai $\mathrm{p}>0,05$ yang berarti tidak mengalami perbedaan kadar kolesterol yang bermakna secara statistik, tetapi penurunan reratanya sebesar 21,866. Hal ini menunjukkan bahwa ekstrak biji ketumbar dosis $700 \mathrm{mg} / \mathrm{kgBB} / \mathrm{hari}$ dapat menurunkan kadar kolesterol darah tikus hiperkolesterolemia diabetes, tetapi penurunanya tidak signifikan dibandingkan kelompok dengan dosis 300 dan 500mg/kgBB/hari.

Tabel 2. Hasil Rerata Kadar Gula Darah Sewaktu

Sumber Tabel: Data Primer, 2020

\begin{tabular}{cccc}
\hline Kelompok Tikus & $\begin{array}{c}\text { Sebelum Penginduksian } \\
\text { Aloksan } \pm \text { SD }\end{array}$ & $\begin{array}{c}\text { Setelah } \\
\text { Penginduksian } \\
\text { Aloksan } \pm \text { SD }\end{array}$ & $\begin{array}{c}\text { Setelah } \\
\text { Perlakuan } \pm \text { SD }\end{array}$ \\
\hline K1 & $103.67 \pm 10.132$ & $114.83 \pm 11.232$ & $130.72 \pm 23.738$ \\
\hline K2 & $126.33 \pm 9.913$ & $269.5 \pm 146.016$ & $120.00 \pm 10.903$ \\
\hline K3 & $159.33 \pm 45.942$ & $283.33 \pm 41.640$ & $185.58 \pm 57.815$ \\
\hline K4 & $126.67 \pm 2.066$ & $350.5 \pm 12.755$ & $174.12 \pm 72.143$ \\
\hline K5 & $136.33 \pm 22.015$ & $354 \pm 27.151$ & $138.10 \pm 38.930$ \\
\hline
\end{tabular}

Penghitungan kadar gula darah sewaktu setelah penginduksian aloksan didapatkan rerata kadar gula darah sewaktu kelompok 2, 3, 4, dan 5 mengalami peningkatan melampaui batas normal yaitu $90-135 \mathrm{mg} / \mathrm{dL}$. Hal ini menunjukkan keberhasilan aloksan dalam penginduksian diabetes pada kelompok tikus tersebut. aloksan akan menyebabkan gangguan sekresi insulin karena aloksan akan mengganggu sensor enzim glukokinase, sehingga tidak terbentuk ATP, sementara ATP diperlukan untuk menutup kanal kalium. Terbukanya kanal kalium tersebut akan menghambat pemasukan kalsium ke dalam sel beta pankreas, sehingga tidak terjadi depolarisasi sel untuk sekresi insulin. Keadaan tersebut akan menyebabkan terjadinya hiperglikemia karena diabetes tipe 1 (Lenzen, 2008, p. 217).

Hasil rerata kadar gula darah sewaktu setelah perlakuan, didapatkan kelompok 2, 3, 4, dan 5 mengalami penurunan setelah perlakuan, hal ini menjelaskan bahwa ekstrak biji ketumbar mampu menurunkan kadar gula darah tikus diabetik yang diinduksi aloksan sejalan dengan penelitian yang dilakukan Yulianty dkk (2015). Penurunan pada kelompok 2 yang diberi glibenklamid $0,045 \mathrm{mg} /$ hari mencapai kadar gula darah sewaktu yang normal, tetapi pada kelompok 3, 4, dan 5 yang diberikan ekstrak biji ketumbar dengan masing-masing dosis 300, 500, dan $700 \mathrm{mg} / \mathrm{kgBB} / \mathrm{hari}$ tidak mencapai kadar normal.

Hasil uji $\mathrm{T}$ berpasangan didapatkan kadar gula darah sewaktu yang dengan nilai $\mathrm{p}<0,05$ atau memiliki perbedaan bermakna pada kelompok 2, 3, 4, dan 5. Hal ini menjelaskan bahwa glibenklamid 0,045mg/hari, ekstrak biji ketumbar 300, 500, dan 700mg/kgBB/hari dapat menurunkan kadar gula darah sewaktu tikus model hiperkolesterolemia diabetes. Penurunan pada kelompok 2 yang diberikan glibenklamid disebabkan karena obat ini berikatan dengan reseptor sulfonil urea di sel $\beta$ Langerhans sehingga kanal kalium tertutup dan kanal kalsium terbuka. Hal ini menyebabkan pelepasan sekresi insulin (Dvm, 2016, p. 359). Penurunan pada 
kelompok 3, 4, dan 5 diakibatkan oleh kandungan flavonoid dari ekstrak biji ketumbar. Flavonoid merupakan $\alpha$-glucosidase inhibitor dan dipeptidyl peptidase (IV) inhibitor. $\alpha$ glucosidase inhibitor bekerja dengan menghambat absorpsi glukosa di usus halus, sedangkan dipeptidyl peptidase (IV) inhibitor bekerja dengan menghambat enzim dipeptidyl peptidase (IV) sehingga memicu aktivitas hormon incretin yang mengakitbatkan sekresi insulin (Sarian et al., 2017, hlm. 4).

Tabel 3. Hasil Rerata Luas Glomerulus

Sumber Tabel: Data Primer, 2020

\begin{tabular}{cc}
\hline Kelompok & $\begin{array}{c}\text { Rerata Luas Glomerulus } \\
\text { Setelah Perlakuan }\left(\mu \boldsymbol{m}^{2}\right) \\
\mathbf{\pm} \text { SD }\end{array}$ \\
\hline K1 & $301476.71 \pm 34752.68$ \\
K2 & $365293.16 \pm 32783.64$ \\
K3 & $425483.90 \pm 81326.42$ \\
K4 & $346958.35 \pm 37594.01$ \\
K5 & $399049.60 \pm 22028.72$ \\
\hline
\end{tabular}

Luas glomerulus dianalisis setelah dilakukan pengambilan gambar dari preparat dengan menggunakan mikroskop cahaya. Hasil penghitungan rerata luas glomerulus didapatkan kelompok 1 sebagai kontrol negatif yang diberikan pakan standar sebesar $301.476,71 \mu m^{2}$, kelompok 2 sebagai kelompok kontrol positif yang diberi glibenklamid sebesar 365.293,16 $\mu^{2}$, kelompok 3 sebagai kelompok perlakuan 1 yang diberikan ekstrak biji ketumbar $300 \mathrm{mg} / \mathrm{kgBB} / \mathrm{hari}$ sebesar $425.483,90 \mu \mathrm{m}^{2}$, kelompok 4 sebagai kelompok perlakuan 2 yang diberikan ekstrak biji ketumbar $500 \mathrm{mg} / \mathrm{kgBB} /$ hari sebesar $346.958,35 \mu \mathrm{m}^{2}$, dan kelompok 5 sebagai kelompok perlakuan 3 yang diberikan ekstrak biji ketumbar 700mg/kgBB/hari sebesar $399.049,66 \mu m^{2}$. Hasil sajian glomerulus masing-masing kelompok dapat dilihat pada gambar 13 .

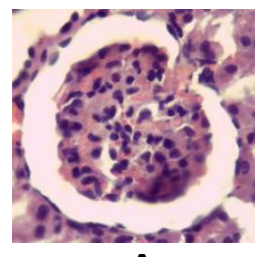

A

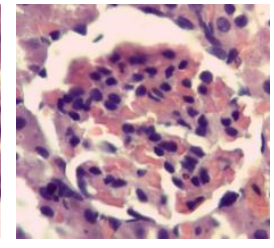

B

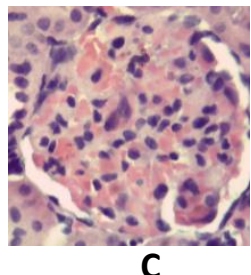

C

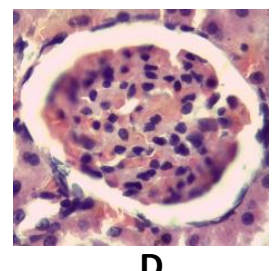

D

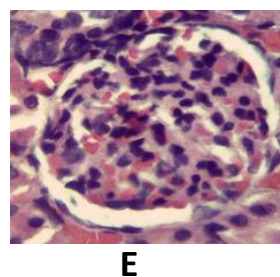

$\mathbf{E}$

Gambar 1. Hasil Sajian Glomerulus Ginjal. H\&E. Pembesaran 400x.

(A) Kontrol Negatif. (B) Kontrol Positif. (C) Perlakuan 1. (D) Perlakuan 2. (E) Perlakuan 3. Sumber Gambar: Data Primer, 2020

Gambar di atas menunjukkan bahwa luas glomerulus pada kelompok kontrol positif, perlakuan 1, perlakuan 2, dan perlakuan 3 lebih besar dibandingkan dengan kontrol negatif. Pada kelompok kontrol positif, perlakuan 1, perlakuan 2, dan perlakuan 3 terdapat ruang Bowman yang lebih sempit dibandingkan dengan kontrol negatif. Hal ini menunjukkan bahwa keadaan hiperglikemi dapat menginduksi terbentuknya Reactive Oxygen Species (ROS) melalui proses glikasi nonenzimatik yang menghasilkan Advanced Glycation End products (AGEs). AGEs dapat berinteraksi dengan reseptornya yatu Receptor Advanced Glycation End-products (RAGE). Jika AGEs berikatan dengan RAGE di makrofag dan sel mesangial dapat menstimulasi pelepasan Transforming Growth Factor- $\beta$ (TGF- $\beta$ ) dan faktor pertumbuhan seperti Connective Tissue 
Growth Factor (CTGF) sehingga terjadi proliferasi sel termasuk sel otot polos pembuluh darah, dan sintesis kolagen yang diikuti dengan fibrosis sehingga dapat menyebabkan terjadinya hipertrofi glomerulus (McCance et al., 2015, p. 746). Interaksi AGE dan RAGE dapat menyebabkan pembentukan ROS. ROS menyebabkan hipertrofi glomerulus, glomerulosklerosis dengan penebalan membran basalis di glomerulus dan ekspansi mesangial serta deposisi protein matriks ekstraseluler (Tan, Forbes and Cooper, 2007, p. 130).

Dilihat secara kualitatif, kelompok dengan pemberian glibenklamid 0,045mg/hari memiliki luas glomerulus yang lebih kecil dibandingkan dengan pemberian ekstrak biji ketumbar $300 \mathrm{mg} / \mathrm{kgBB} /$ hari, tetapi tidak lebih kecil dibandingkan dengan pemberian ekstrak biji ketumbar $500 \mathrm{mg} / \mathrm{kgBB} /$ hari. Pemberian ekstrak biji ketumbar yang paling efektif dalam menurunkan luas glomerulus adalah kelompok dengan dosis $500 \mathrm{mg} / \mathrm{kgBB} / \mathrm{hari}$. Uji Kruskal Wallis dilakukan untuk mengetahui apakah terdapat perbedaan bermakna antar kelompok secara statistik.

Uji Kruskal Wallis menunjukkan nilai $\mathrm{p}<0,05$ yang berarti bahwa terdapat perbedaan bermakna pada setiap kelompok, maka dilakukan uji Mann-Whitney untuk mengetahui kelompok mana yang memiliki perbedaan bermakna.

Hasil uji Mann-Whitney kelompok kontrol negatif dan perlakuan 2 menunjukkan perbedaan tidak bermakna yang menjelaskan bahwa pemberian ekstrak biji ketumbar $500 \mathrm{mg} / \mathrm{kgBB} / \mathrm{hari}$ dapat menurunkan luas glomerulus hingga setara normal. Hal ini diakibatkan oleh kandungan flavonoid yang terdapat pada biji ketumbar. Flavonoid berperan sebagai antioksidan. Antioksidan dapat menangkap radikal bebas dan memutus reaksi berantai dengan cara memberi atom hidrogen secara cepat ke radikal lipid (Suryohudoyo, 1993, hlm. 9). Antioksidan dapat melawan kerusakan yang disebabkan oleh ROS dan radikal bebas lainnya (Kurniasih et al., 2015, hlm. 168). Jejas yang terjadi pada kelompok perlakuan 2 bersifat reversibel sehingga kandungan biji ketumbar tersebut dapat menurunkan hipertrofi glomerulus setara dengan normal. Luas glomerulus antara kelompok kontrol negatif dan kontrol positif menunjukkan perbedaan yang bermakna, tetapi luas glomerulus antara kelompok kontrol positif dan perlakuan 2 tidak memiliki perbedaan bermakna. Hal ini menjelaskan bahwa pemberian glibenklamid $0,045 \mathrm{mg}$ dapat menurunkan hipertrofi glomerulus setara dengan kelompok yang diberikan ekstrak biji ketumbar $500 \mathrm{mg} / \mathrm{kgBB} /$ hari tetapi tidak dapat menurunkan hipertrofi glomerulus hingga normal.

Luas glomerulus kelompok perlakuan 1 yang diberikan ekstrak biji ketumbar 300mg/kgBB/hari memiliki luas glomerulus yang paling besar di antara semua kelompok. Hasil uji Mann-Whitney pada kelompok perlakuan 1 dan kontrol negatif memiliki perbedaan yang bermakna. Perbedaan ini menjelaskan bahwa luas glomerulus kelompok yang diberikan ekstrak biji ketumbar $300 \mathrm{mg} / \mathrm{kgBB} /$ hari tidak dapat menurunkan hipertrofi glomerulus setara normal, tetapi kelompok perlakuan 1 tidak memiliki perbedaan yang bermakna dengan kelompok perlakuan 2. Hal ini menjelaskan bahwa kelompok yang diberikan ekstrak biji ketumbar 300mg/kgBB/hari dapat menurunkan hipertrofi glomerulus setara dengan pemberian ekstrak biji ketumbar $500 \mathrm{mg} / \mathrm{kgBB} / \mathrm{hari}$ tetapi tidak dapat menurunkan hipertrofi glomerulus setara normal. Hal ini diduga karena zat aktif flavonoid dalam dosis tersebut tidak cukup menimbulkan efek antioksidan untuk menurunkan hipertrofi glomerulus hingga normal.

Hasil uji menunjukkan luas glomerulus antara kontrol negatif dan perlakuan 3 memiliki perbedaan bermakna. Perbedaan tersebut menjelaskan bahwa luas glomerulus kelompok yang diberikan ekstrak biji ketumbar 700mgkgBB/hari tidak setara dengan normal. Luas glomerulus antara kelompok perlakuan 2 dan perlakuan 3 menunjukkan perbedaan bermakna, yang berarti 
bahwa kelompok yang diberikan ekstrak biji ketumbar $700 \mathrm{mg} / \mathrm{kgBB} / \mathrm{hari}$ tidak setara dengan kelompok yang diberikan ekstrak biji ketumbar 500mg/kgBB/hari . Kedua hal ini diduga karena destruksi glomerulus yang disebabkan radikal bebas yang ditimbulkan akibat hiperglikemi bersifat irreversibel sehingga dosis ekstrak biji ketumbar yang paling besar di penelitian ini sekalipun yaitu $700 \mathrm{mg} / \mathrm{kgBB} / \mathrm{hari}$ tidak menimbulkan efek yang bermakna untuk menurunkan hipertrofi glomerulus.

Luas glomerulus antara kelompok kontrol positif dan perlakuan 1, memiliki perbedaan yang tidak bermakna. Hal ini menunjukkan bahwa pemberian glibenklamid 0,045mg/hari dan ekstrak biji ketumbar 300mg/kgBB/hari memiliki efek yang setara terhadap hipertrofi glomerulus tikus model hiperkolesterolemia diabetes. Hasil uji antara kelompok perlakuan 3 dan kontrol positif tidak memiliki perbedaan bermakna yang berarti bahwa luas glomerulus antara kelompok yang diberikan ekstrak biji ketumbar $700 \mathrm{mg} / \mathrm{kgBB} /$ hari dan pemberian glibenklamid $0,045 \mathrm{mg} / \mathrm{hari}$ memberikan efek yang setara terhadap hipertrofi glomerulus pada tikus model hiperkolesterolemia diabetes. Hasil uji antara kelompok perlakuan 3 dan perlakuan 1 tidak memiliki perbedaan bermakna yang berarti bahwa luas glomerulus antara kelompok yang diberikan ekstrak biji ketumbar $700 \mathrm{mg} / \mathrm{kgBB} /$ hari dan $300 \mathrm{mg} / \mathrm{kgBB} /$ hari memberikan efek yang setara terhadap hipertrofi glomerulus pada tikus model hiperkolesterolemia diabetes.

Hasil penelitian dan uji statistik yang telah dilakukan membuktikan bahwa ekstrak biji ketumbar dapat menurunkan kadar kolesterol darah, gula darah sewaktu, dan hipertrofi glomerulus pada tikus hiperkolesterolemia diabetes. Hal ini sejalan dengan penelitian yang dilakukan oleh Kajal dan Sing pada tahun 2019 bahwa ekstrak biji ketumbar memiliki zat aktif flavonoid sebagai antidiabetes, antikolesterol, dan antioksidan.

\section{KESIMPULAN DAN SARAN}

\section{Kesimpulan}

Dosis ekstrak biji ketumbar yang paling efektif dalam menurunkan kadar kolesterol darah tikus model hiperkolesterolemia diabetes adalah $300 \mathrm{mg} / \mathrm{kgBB} / \mathrm{hari}$ dan $500 \mathrm{mg} / \mathrm{kgBB} / \mathrm{hari}$. Dosis ekstrak biji ketumbar yang paling efektif dalam menurunkan kadar gula darah sewaktu tikus model hiperkolesterolemia diabetes adalah $300 \mathrm{mg} / \mathrm{kgBB} / \mathrm{hari}, \quad 500 \mathrm{mg} / \mathrm{kgBB} / \mathrm{hari}$, dan $700 \mathrm{mg} / \mathrm{kgBB} /$ hari. Glibenklamid $0,045 \mathrm{mg}$ memiliki efek yang lebih efektif untuk menurunkan kadar gula darah sewaktu tikus hiperkolesterolemia diabetes kembali normal dibandingkan ekstrak biji ketumbar 300, 500, dan 700mg/kgBB/hari. Dosis ekstrak biji ketumbar yang paling efektif dalam menurunkan hipertrofi glomerulus tikus model hiperkolesterolemia diabetes adalah $500 \mathrm{mg} / \mathrm{kgBB} / \mathrm{hari}$.

\section{Saran}

Perlu dilakukan penelitian lanjutan dosis maksimum ekstrak biji ketumbar sebagai terapi. Perlu dilakukan uji toksisitas ekstrak biji ketumbar. Perlu dilakukan penelitian lanjutan efektivitas ektsrak biji ketumbar terhadap kadar kreatinin serum dan BUN untuk memastikan hasil yang lebih signifikan. Perlu dilakukan efek ekstrak biji ketumbar terhadap organ-organ lain.

\section{Ucapan Terima Kasih}

Penulis mengucapkan terima kasih kepada Kepala Laboratorium Farmakologi dan Terapi Fakultas Kedokteran UNPAD telah bersedia berkerjasama dalam melakukan penelitian dan terima kasih kepada Dr. dr. Maria Selvester Thadeus, M. Biomed dan dr. Niniek Hardini, Sp. PA atas saran, bimbingan, dan bantuannya. 


\section{REFERENSI}

Dahlan, Sopiyudin. (2014). Statistik Untuk Kedokteran dan Kesehatan Edisi 6. Salmba Medika. Jakarta.

Dvm, MGP. (2016). Saunders Handbook of Veterinary Drugs Small and Large Animal, 4th edn. ELSEVIER.

Gross, JL, Azevedo, MJD, Silveiro, SP, Canani, LH, Caramori, ML, Zelmanovitz, T. (2005). Kaplow Shavell Fairness v Welfare Chapter 3.pdf. Diabetic Nephropathy: Diagnosis, Prevention, and Treatment. Diakses 10 Juli 2019. Available at : https://doi.org/10.2337/diacare.28.1.164.

Hao, M, Head, WS, Gunawardana, SC, Hasty, AH, Piston, DW. (2007). A Novel Mechanism for Pancreatic 'Cell Dysfunction', 56(September). Diakses 31 Julia 2019. doi: 10.2337/db070056.2-DG.

Joshi, SC, Sharma, N, Sharma, P. (2012). Antioxidant and lipid lowering effects of Coriandrum sativum in cholesterol fed rabbits. International Journal of Pharmacy and Pharmaceutical Sciences, 4(SUPPL.3), pp. 231-234. Diakses 28 Januari 2020. Available at: https://www.researchgate.net/publication/267037167_Antioxidant_and_lipid_lowering_eff ects_of_Coriandrum_sativum_in_cholesterol_fed_rabbits

Kajal, A \& Singh, R. (2019). Coriandrum sativum seeds extract mitigate progression of diabetic nephropathy in experimental rats via AGEs inhibition, PLoS ONE, 14(3), pp. 1-13. Diakses 1 Juli 2019. doi: 10.1371/journal.pone.0213147

Kasper, DL, Hauser, SL, Jameson, JL, Fauci, AS, Longo, DL, Loscalzo, J. (2015). Harrison's Principles of Internal Medicine, $19^{\text {th }}$ edn. McGraw Hill. USA.

Kisaoglu, A, Borekci, B, Yapca, OE, Bilen, H, Suleyman, H. (2013). Tissue Damage and Oxidant/Antioxidant Balance, The Eurasian Journal of Medicine, 45(1), pp. 47-49. Diakses 17 Juli 2019. doi: 10.5152/eajm.2013.08.

Kurniasih, N, Kusmiyati, M, Nurhasanah, Sari, RP, Wafdan, R. (2015). Potensi Daun Sirsak ( Annona muricata Linn ), Daun Binahong ( Anredera cordifolia ( Ten ) Steenis ), dan Daun Benalu Mangga ( Dendrophthoe pentandra ) Sebagai Antioksidan Pencegah Kanker. Jurnal Edisis, IX(1), pp. 162-184. Diakses 17 Juli 2019. Available at: http://www.journal.uinsgd.ac.id/index.php/istek/article/viewFile/182/197.

Lenzen, S. (2008). The mechanisms of alloxan- and streptozotocin-induced diabetes, Diabetologia, 51(2), pp. 216-226. Diakses 17 Juli 2019. doi: 10.1007/s00125-007-0886-7.

McCance, KL, Huether, SE, Brashers, VL, and Rote, NS. (2015). Pathophysiology: The Biologic Basis For Disease In Adults And Children, $7^{\text {th }}$ edn. ELSEVIER. Canada.

Mughal, MA, Aamir, K, Ali, M. (2019). The effects of glibenclamide on serum lipids and lipoproteins in type II non-insulin dependent diabetes mellitus. Journal of the Pakistan Medical Association, 49(4), pp. 89-92.

Perkumpulan Endorinologi Indonesia (PERKENI). (2015). Konsensus Pengendalian dan Pencegahan Diabetes Melitus Tipe 2 di Indonesia 2015. PERKENI. Jakarta. Diakses 17 Juli 2019. Available at: https://doi.org/10.1017/CBO9781107415324.0041

Pietta, PG. (2000). Flavonoids as antioxidants. Journal of Natural Products, 63(7), pp. 10351042. Diakses 5 Juli 2019. doi: 10.1021/np9904509.

Rao, V, Sean, HT, Candasamy, M, Bhattamisra, SK. (2019). Diabetic nephropathy: An update on pathogenesis and drug development. Diabetes and Metabolic Syndrome: Clinical Research and Reviews. Elsevier Ltd, 13(1), pp. 754-762. doi: 10.1016/j.dsx.2018.11.054. Available from: https://www.sciencedirect.com/science/article/abs/pii/S1871402118305277?via\%3Dihub Sarian, MN, Ahmed, QU, So'ad, SZM. (2017). Antioxidant and antidiabetic effects of 
flavonoids: A structure-activity relationship based study. BioMed Research International. Hindawi. 2017. Diakses 17 Juli 2019. doi: 10.1155/2017/8386065.

Suryohudoyo, P. (1993). Oksidan, Antioksidan dan Radikal Bebas, Laboratorium Biokimia Fakultas Kedokteran Unair, pp. 1-11.

Tan, ALY, Forbes, JM and Cooper, ME. (2007). AGE, RAGE, and ROS in Diabetic Nephropathy, Seminars in Nephrology. W.B. Saunders, 27(2), pp. 130-143. Diakses 5 Juli 2019. doi: 10.1016/J.SEMNEPHROL.2007.01.006.

Yulianty, O, Sudiastuti, Nugroho. (2015). Efek Ekstrak Biji Ketumbar (Coriandrum sativum L.) terhadap Histologi Pankreas Mencit (Mus musculus L.) Diabetik Aloksan', (November 2014). 
